\title{
PENERAPAN RANCANG BANGUN pH METER BERBASIS ARDUINO PADA MESIN PENCUCI FILM RADIOGRAFI SINAR-X
}

\section{APPLICATION DESIGN OF pH-METER BASED ON ARDUINO TO WASHING MACHINE OF X-RAY RADIOGRAPH FILM}

\author{
Muchamad Ngafifuddin*, Susilo dan Sunarno \\ Jurusan Fisika, Fakultas Matematika dan Ilmu Pengetahuan Alam Universitas Negeri Semarang \\ *email: afiffeifa@gmail.com
}

Diterima 10 April 2017, disetujui 20 April 2017

\begin{abstract}
Abstrak
Perancangan $\mathrm{pH}$ meter berbasis Arduino dilakukan untuk membuat alat ukur $\mathrm{pH}$ yang kompatibel dengan alat mesin pencuci film otomatis. Pengukuran $\mathrm{pH}$ pada larutan fixer sangat diperlukan karena tingkat $\mathrm{pH}$ sangat berpengaruh terhadap hasil citra radiografi. Pada penelitian ini telah dilakukan rancang bangun $\mathrm{pH}$ meter berbasis Arduino Uno. Rancang bangun alat ini menggunakan sensor E-201C, Arduino Uno, dan tampilan PC. Pengambilan data dilakukan menggunakan variasi larutan buffer. Hasil dari karakterisasi sensor menunjukkan sensor memiliki nilai sensitivitas $46,2 \mathrm{mV} / \mathrm{pH}$ pada suhu $28 \mathrm{oC}$. Pengukuran pada larutan asam menghasilkan tegangan sensor bernilai positif, larutan netral menghasilkan tegangan sensor mendekati nol, dan larutan basa menghasilkan tegangan sensor bernilai negatif. Berdasarkan hasil pengujian, $\mathrm{pH}$ meter yang dibuat mampu mengukur rentang nilai pH 1,6 sampai dengan 11 dengan ketelitian 99\% dan layak digunakan sebagai alat ukur $\mathrm{pH}$ pada mesin pencuci film radiografi.
\end{abstract}

Kata Kunci : Larutan fixer, sensor E-201C, Arduino Uno, pH meter

\begin{abstract}
Design of $\mathrm{pH}$ meter based on Arduino had been done to create $\mathrm{pH}$ measurement instrument that compatible with automatic washing machine of $x$-ray radiograph film. The pH measurement on buffer solution is important because acidic level extremely affect the result of radiograph image. In this research, the design of pH meter based on Arduino Uno had been performed. E-201C sensor, Arduino Uno and display PC were used to design the pH meter. Buffer solution was variated to get a data result. The result of sensor characterization shows that the sensitivity of the sensor is about $46.2 \mathrm{mV} / \mathrm{pH}$ in the temperature of $28 \mathrm{C}$. Measurement of acidic solution give result to positive voltage, netral solution give voltage to zero, and base solution to negative voltage. According to the examination result, $\mathrm{pH}$ meter which had been made can measure $\mathrm{pH}$ with ranges of 1,6 to 11 within $99 \%$ accuracy and proper to be used as a pH measuring instrument in washing film radiography equipment.
\end{abstract}

Keywords : Buffer Solution, Sensor of E-201C, Arduino Uno, pH meter

\section{Pendahuluan}

$\mathrm{pH}$ adalah jumlah konsentrasi ion Hidrogen $\left(\mathrm{H}^{+}\right)$pada larutan yang menyatakan tingkat keasaman dan kebasaan yang dimiliki. $\mathrm{pH}$ merupakan besaran fisis dan diukur pada skala 0 sampai 14 [1]. Bila $\mathrm{pH}<7$ larutan bersifat asam, $\mathrm{pH}>7$ larutan bersifat basa dan $\mathrm{pH}=7$ larutan bersifat netral [2]. Pengukuran $\mathrm{pH}$ biasanya dilakukan dengan menggunakan $\mathrm{pH}$ meter. Salah satu pengukuran dengan memanfaatkan $\mathrm{pH}$ meter adalah pengukuran $\mathrm{pH}$ pada larutan mesin pencuci film radiografi.
Proses pencucian film merupakan langkah untuk menghasilkan gambar tampak yang berasal dari gambar laten hasil foto sinar-X. Pemanfaaatan sinar- $X$ dengan energi rendah di bidang kedokteran terutama untuk radio diagnostik, seperti pembuatan citra radiografi konvensional [3]. Salah satu faktor yang mempengaruhi hasil citra radiografi adalah konsentrasi ion $\mathrm{H}^{+}(\mathrm{pH})$ larutan fixer mesin pencuci film. Nilai $\mathrm{pH}$ berpengaruh terhadap densitas dari hasil citra radiografi [4]. Konsentrasi larutan fixer rendah dapat digunakan untuk pencucian perak pada fotografi [5]. Larutan fixer untuk bekerja secara 
optimum memiliki konsentrasi pH 4,0 - 5,0 [6]. Kemampuan larutan fixer untuk menetapkan gambar semakin lama akan semakin berkurang setelah digunakan berulang - ulang untuk proses fiksasi gambar [7].

$\mathrm{pH}$ meter merupakan alat yang dapat mengukur tingkat $\mathrm{pH}$ larutan. Sistem pengukuran dalam $\mathrm{pH}$ meter menggunakan sistem pengukuran secara potensimetri. $\mathrm{pH}$ meter berisi elektroda kerja dan elektroda referensi. Perbedaan potensial antara dua elektroda tersebut sebagai fungsi dari $\mathrm{pH}$ dalam larutan yang diukur [8]. Sinyal tegangan yang dihasilkan pada pengukuran dengan elektrode $\mathrm{pH}$ berada pada kisaran $\mathrm{mV}$, sehingga perlu diperkuat dengan penguat operasional [9].

Rangkaian penguat operasional adalah suatu perangkat yang dapat memperkuat sinyal input ac maupun dc. Penguat operasional dapat digunakan untuk menambah, mengintegrasikan, dan membandingkan sinyal tegangan [10]. Biasanya output dari op-amp dikendalikan baik dengan cara umpan balik negatif yang sangat menentukan besarnya gain tegangan output, atau dengan umpan balik positif yang memfasilitasi gain pembanding dan osilasi [11]. Sinyal keluaran penguat operasional menghasilkan tegangan dalam orde volt dan diolah mikrokontroler Arduino Uno. Arduino board dapat menerima input data dari sensor analog maupun digital dan mengatur output komponen elektronika [12].

Di laboratorium fisika medik UNNES pengukuran $\mathrm{pH}$ pada mesin pencuci film masih dilakukan dengan cara manual. Pengukuran secara manual ini tidak kompatibel dengan mesin pencuci film radiografi otomatis. Perancangan $\mathrm{pH}$ meter berbasis Arduino digunakan untuk membuat alat $\mathrm{pH}$ meter yang

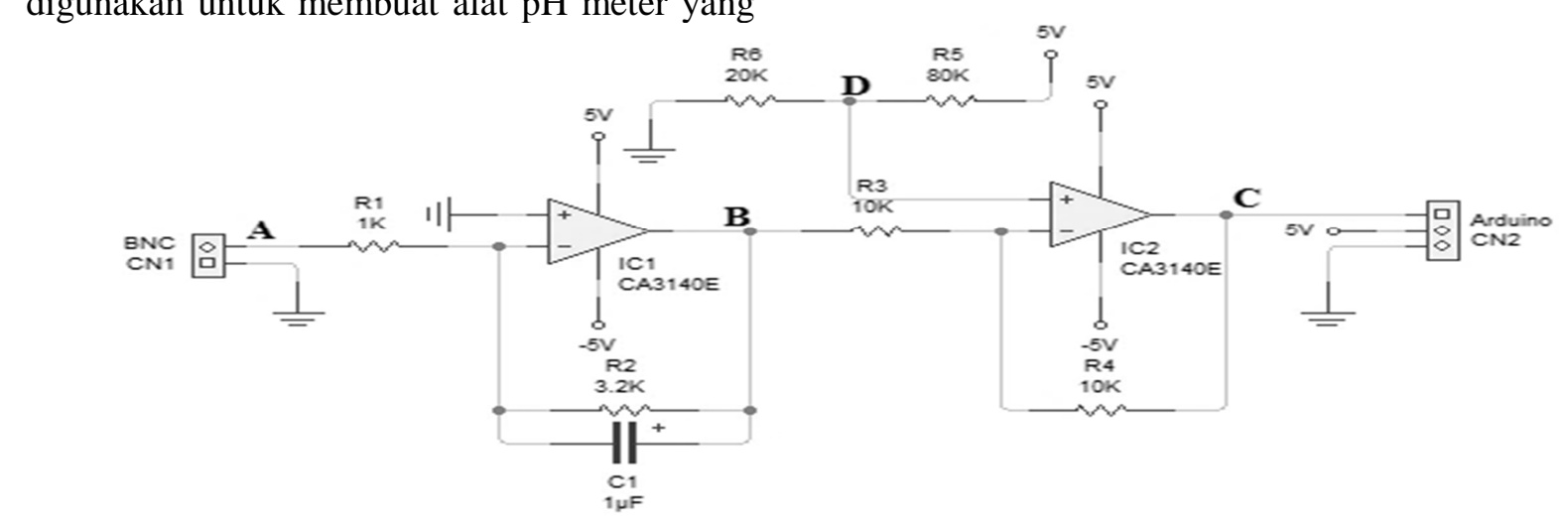

Gambar 2. Skema Rangkaian Pengkondisian Sinyal kompatibel dengan mesin pencuci film otomatis.

\section{Metode Penelitian}

Perancangan sistem meliputi pembuatan rancangan perangkat keras dan perangkat lunak. Skema perancangan perangkat keras dapat dilihat pada Gambar 1 sebagai berikut :

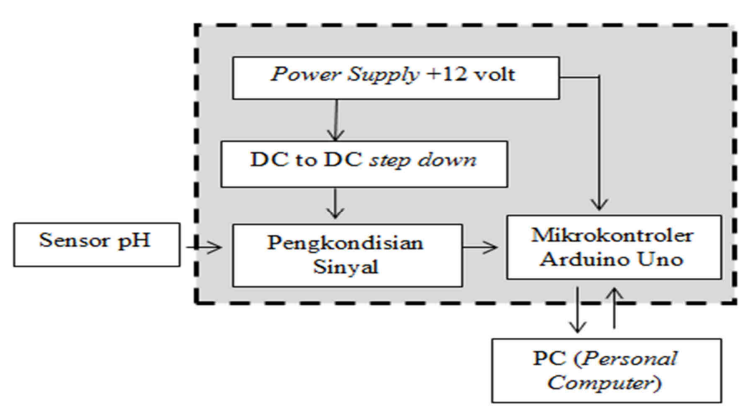

Gambar 1. Skema Rancang Bangun pH Meter

Dari skema rancang bangun $\mathrm{pH}$ meter ini dapat dijelaskan sistem kerja perangkat secara menyeluruh. Sensor $\mathrm{pH}$ akan membaca nilai $\mathrm{pH}$ larutan dan mengubahnya menjadi besaran listrik. Sinyal keluaran dari sensor $\mathrm{pH}$ memiliki nilai tegangan yang sangat kecil sehingga perlu diperkuat dengan rangkaian pengkondisian sinyal. Hasil keluaran dari rangkaian pengkondisian sinyal yang masuk ke mikrokontroler Arduino Uno diolah dan selanjutnya ditampilkan pada PC.

Rangkaian pengkondisian sinyal dibangun menggunakan rangkaian tapis aktif lolos rendah orde pertama dan rangkaian differensial. Adapun skema rangkaian pengkondisian sinyal dapat dilihat pada Gambar 2

Gambar 2. Skema Rangkaian Pengkondisian Sinyal 

Pada penelitian ini, perancangan perangkat lunak menggunakan software Arduino 1.6.7. Diagram alir program dapat dilihat pada Gambar 3.

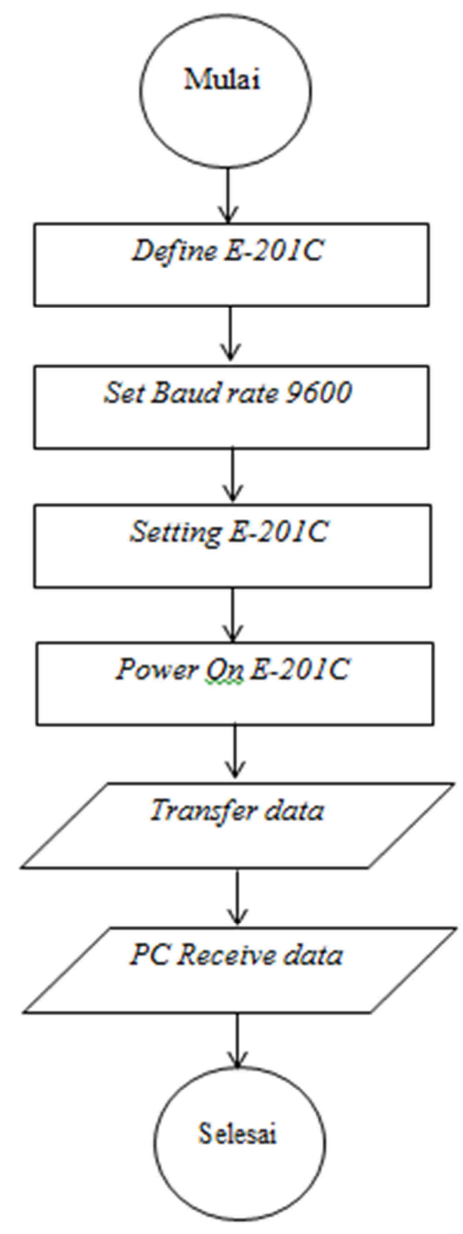

Gambar 3. Diagram Alir Program

\section{Hasil dan Pembahasan}

Pengujian pada penelitian ini meliputi pengujian sensor, pengujian rangkaian pengkondisian sinyal, dan kalibrasi alat. Pengujian dilakukan untuk mengetahui kesesuaian sistem dengan data atau kondisi yang diinginkan.

\section{A. Pengujian Sensor}

Pengujian sensor bertujuan untuk mengetahui karakteristik sensor E-201C. Pengujian dilakukan dengan mengukur larutan buffer yang divariasikan. Hasil pengujian sensor ditunjukkan pada Gambar 4.

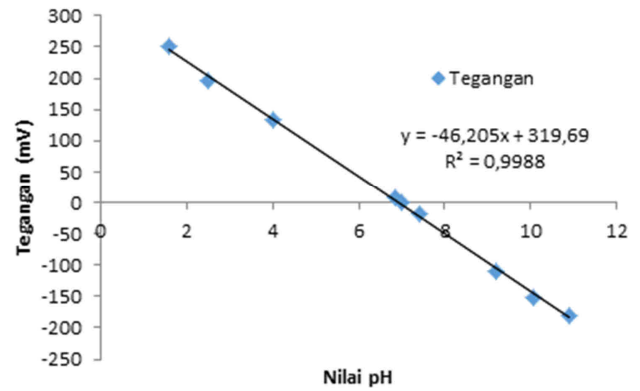

Gambar 4. Hasil Pengujian Sensor

Pada pengujian sensor terjadi penurunan tegangan yang dihasilkan seiring dengan bertambahnya nilai $\mathrm{pH}$, seperti yang ditunjukkan dengan Gambar 4. Tegangan keluaran yang didapat memiliki rentang -180 sampai dengan +251 milivolt untuk rentang $\mathrm{pH}$ 1,6 - 10,9. Hasil pengujian sensor menunjukkan bahwa nilai tegangan keluaran sensor pada pengukuran larutan asam menghasilkan tegangan bernilai positif, sedangkan pengukuran larutan basa menghasilkan tegangan bernilai negatif dan pada pengukuran larutan netral menghasilkan nilai yang mendekati nol [13]. Gambar 4 menunjukkan nilai sensitivitas dari sensor probe E-201C berada pada nilai 46,2 milivolt per $\mathrm{pH}$ pada suhu $28^{\circ} \mathrm{C}$.

\section{B. Pengujian Rangkaian Pengkondisian Sinyal \\ Pengujian rangkaian pengkondisian sinyal} bertujuan untuk memperoleh penguatan tegangan yang diinginkan agar keluaran sensor dapat ditanggapi oleh ADC mikrokontroler pada kisaran 0 - 5 volt.

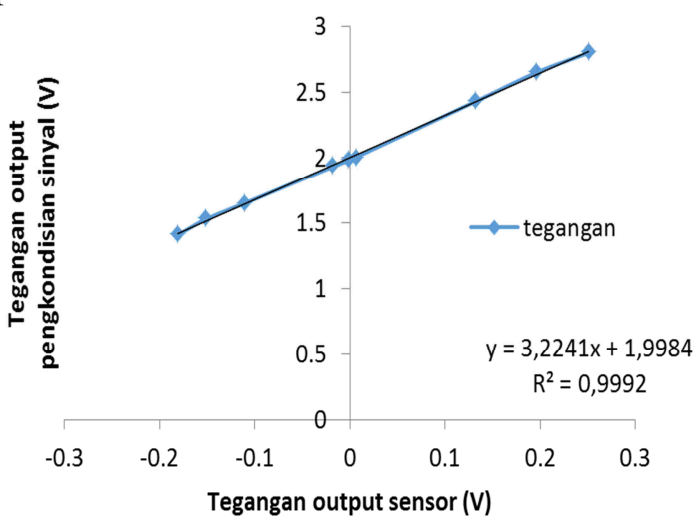

Gambar 5. Hasil Pengujian Rangkaian Pengkondisian Sinyal 
Dari Gambar 5 diperoleh nilai regresi 0,9992 . Hal ini berarti bahwa grafik hubungan antara tegangan output sensor dan tegangan output rangkaian pengkondisian sinyal menunjukkan grafik yang linier. Rangkaian pengkondisian sinyal ini menghasilkan penguatan sebesar 3,2 kali.

\section{Kalibrasi Alat}

Pengujian ini bertujuan untuk mengetahui ketepatan dari alat ukur yang telah dibuat. Pengujian dilakukan dengan cara mengukur nilai $\mathrm{pH}$ buffer yang sama menggunakan dua alat tersebut dan memvariasikan $\mathrm{pH}$ buffer yang digunakan. Sebelum pengujian dilakukan, kedua alat tersebut dikalibrasi dengan menggunakan larutan buffer $\mathrm{pH} 4$ dan $\mathrm{pH} 7$. Larutan buffer $\mathrm{pH} \quad 4$ dan $\mathrm{pH} \quad 7$ dapat menentukan ketepatan hasil pengukuran nilai $\mathrm{pH}$ [14].

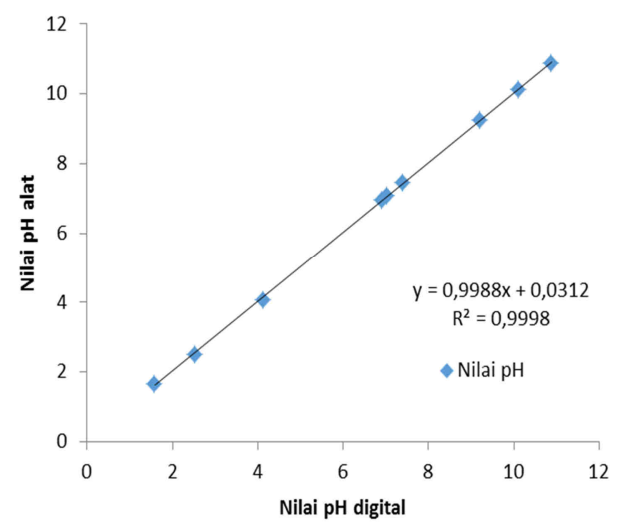

Gambar 6. Hasil Kalibrasi Alat

Gambar 6 didapatkan persamaan $y=$ $0,9999 x+0,0321$ dan nilai $R^{2}$ sebesar 0,9998. Persamaan $\quad y=0,9999 x+0,0321$ menyatakan bahwa nilai variabel $y$ dipengaruhi oleh variabel $x$. Nilai $0,9999 x$ menyatakan bahwa nilai keterbacaan dari grafik $99 \%$ sama. Hal ini dapat dikatakan $\mathrm{pH}$ meter digital yang telah dibuat memiliki karakteristik pembacaan nilai $\mathrm{pH}$ yang hampir sama dengan $\mathrm{pH}$ meter digital 107.

\section{Simpulan}

Telah dibuat alat $\mathrm{pH}$ meter digital dengan menggunakan sensor E-201C berbasis Arduino Uno. Sensor E-201C dapat digunakan sebagai sensor $\mathrm{pH}$ dengan tingkat sensitivitas 46,2 milivolt per $\mathrm{pH}$ pada suhu $28^{\circ} \mathrm{C}$. Pengukuran pada larutan asam menghasilkan tegangan sensor bernilai positif, sedangkan larutan netral menghasilkan tegangan sensor mendekati nol, dan untuk larutan basa menghasilkan tegangan sensor bernilai negatif.

Perangkat ini mampu mengukur rentang nilai $\mathrm{pH}$ 1,6 sampai dengan 11 dengan resolusi 0,01 dan ketelitian 99\% sehingga layak digunakan sebagai alat ukur $\mathrm{pH}$ pada mesin pencuci film radiografi.

\section{Ucapan Terima Kasih}

Penulis mengucapkan terima kasih kepada semua pihak yang membantu kami dalam pembuatan artikel ini.

\section{Pustaka}

[1] Astria F., M. Subito, D.W. Nugraha. (2014), Rancang Bangun Alat Ukur pH dan Suhu Berbasis Short Message Service (SMS) Gateway, Jurnal Mektrik, $1(1): 47-55$.

[2] Ihsanto E, S. Hidayat. (2014), Rancang Bangun Sistem Pengukuran Ph Meter dengan Menggunakan Mikrokontroller Arduino Uno, Jurnal Teknik Elektro, 3(5) : 139-146.

[3] Susilo, Maesadji T.N., Kusminarto Wahyu S.B. (2011), Uji Diagnostik Pemeriksaan Osteosk $\neg$ lerotik Tulang Dengan Sistem Radiografi Diᄀgital, M Med Indones.

[4] Zusagka E., H. Sutanto, Z. Arifin. (2014), Pengaruh Peningkatan pH cairan Developer dengan Penambahan Antara $\mathrm{NaOH}$ dan $\mathrm{Na} 2 \mathrm{CO} 3$ Terhadap Densitas Citra, Youngster Physics Journal. 3(3) : 203-208.

[5] Orubite O. K, I.R. Jack. (2012), Estimation of silver content in some photographic wastes, American Journal Of Scientific and Industrial Reseach. 3(6): 390-394.

[6] Kajul. (2014), Larutan Fixer Radiografi, Online, Tersedia di http://extraradiation.blogspot.co.id / [diakses 29- 2- 2016].

[7] Kesumayadi D., H. Susanto. (2015), 
Studi Pengendapan Perak pada Limbah Fixer yang Telah Jenuh dengan Metode Pembakaran dan Pengendapan $\mathrm{NaOH}$ dan Na2S, Youngster Physics Journal, 4(1) : 111-116.

[8] Rifky A., Faiqoturrifda, A.N. Shochib. (2014), Pengukuran Sensor pH Larutan Disimpan pada Kartu SD, Semarang : Politeknik Negeri Semarang.

[9] Ramya V., B. Palaniappan. (2012), Embeddeb $\mathrm{pH}$ Data Acquisition and Logging, Advanced Computing: An International Journal ( ACIJ ), 1 (3) : 4563.

[10] Poonam, M. Duhan, H. Saini. (2013), Design of Two Stage Op-Amp, International Journal of Advanced Trends in Computer Science and Engineering, 2 (3) : 50-53.

[11] Tapashetti P., A. Gupta., C. Mithlesh, A.S Umesh. (2012), Design and
Simulation of Op Amp Integrator and Its Applications, International Journal of Engineering and Advanced Technology (IJEAT), 1(3) : 12-19.

[12] Isnaini V.A. (2013), Pemanfaatan Modul Mikrokontroller Arduino untuk Rancang Bangun Alat Ukur Fisika, Edu-physic (1) : 116-125.

[13] Ghodki V.M., S. Rajagopalan, S.J. Sharma. (2012), Design of Virtual Instrumentation for $\mathrm{pH}$ Measurenments, Prosiding International Conference on Benchmarks in Engineering Science and Technology (ICBEST). International Journal of Computer Applications (IJCA).

[14] Pambudi P.E., E. Utanta, Mujiman. (2014), Identifikasi Daging Segar dan Busuk Menggunakan Sensor Warna RGB dan $\mathrm{pH}$ Meter Digital, Jurnal Teknologi Technoscientia, 7(1) : 46-53. 